\title{
A study into the mobility of iron in podzolized Sarawak upland soils by means of selective iron extractions
}

\section{J. P. Andriesse}

Department of Agricultural Research, Royal Tropical Institute, Amsterdam, the Netherlands

Accepted: 29 March 1978

Key words: iron mobility, selective iron extractions, podzolic weathering, oxisols, ultisols

\section{Summary}

An evaluation is given of existing iron extraction methods which were tested on major upland soils from Sarawak. The results indicate the presence of relatively large amounts of crystalline free iron oxides gradually increasing with depth, a virtual absence of new iron accumulations in the amorphous form and a great activity of organic acids in complexing iron in surface horizons. Additional field information provides evidence of large accumulations of iron oxides at great depth in cracks and joints of sedimentary rocks. These characteristics may be explained by the following reasoning.

In all soils investigated, there has been relative accumulation of crystalline iron oxides through desilication during an early stage in soil formation. This was followed by a loss of iron in varying degree from the upper horizons, which can most likely be attributed to fossil argilluviation and weathering of iron-rich clay, or possibly to fossil reduction with transport in ferrous form. The latter would presuppose poorly drained conditions prior to the strong dissection resulting in the present landscape.

The strong and extensive accumulation of iron oxides at great depth in cracks and joints may be attributed to the oxidation and precipitation of ferrous and ferric iron mobilized upon initial oxidation of pyrites in the weathering front of the sedimentary rocks. Lateral movements of soil water may play a role in this.

The fact that pyrophosphate-extractable iron appears to exceed oxalate-extractable iron in most soils, in contrast to the situation in temperate regions, may point to a difference in the nature of the iron-organic complexes, which is worth further investigation. (See note on page 12.)

\section{Review of iron extraction methods}

During the previous decade much attention has been given to the study of the nature and amounts of secondary iron and aluminium forms in soils, with the aim to 
relate these to soil forming processes and classification.

Schwertmann (1959) revived the well-known Tamm's method of extracting amorphous iron with ammonium oxalate and, after modification, the method has been successfully used by Schwertmann (1964), McKeague \& Day (1966) and by Blume \& Schwertmann (1969) to differentiate amorphous secondary iron (including that bound to organic matter) from total secondary or free iron, the latter being extracted by dithionite-citrate-bicarbonate (Mehra \& Jackson, 1960). The difference between the two obtained values comprises the crystalline oxides.

The ratio between oxalate-extractable ron $\left(\mathrm{Fe}_{0}\right)$ and dithionite-extractable iron $\left(\mathrm{Fe}_{\mathrm{d}}\right)$ has been used by Blume \& Schwertmann (1969) as a relative measure of the degree of aging or crystallinity of free iron oxides and is therefore called the 'activity ratio' or $\mathrm{Fe}_{\mathrm{o}} / \mathrm{Fe}_{\mathrm{d}}$ ratio. This ratio was applied with success to differentiate bestween main soil horizons in soils of Germany.

It should be noted that Baril \& Bitton (1967) discovered that the oxalate extraction also removes appreciable amounts of iron from magnetite and the usefulness of this extraction for soils rich in this mineral is therefore somewhat diminished.

McKeague (1966) \& Bascomb (1968) contributed to this new development by suggesting a method which made it possible to distinguish between inorganic amorphous iron compounds and those of organic complexed nature. The latter are present particularly in podzolic soils. The authors successfully tested the use of pyrophosphate extraction for the organic complexed iron forms on a number of Canadian soils and suggest that the difference between $\mathrm{Fe}_{0}$ and $\mathrm{Fe}_{\mathrm{p}}$ (pyrophosphateextractable iron) would be a good measure for amorphous inorganic iron.

However, Bascomb (1968) found that potassium pyrophosphate extracted both organic iron and fresh (not aged) amorphous iron oxides.

Apparently, as a result of these findings Ball \& Beaumont (1972) regards the $\mathrm{Fe}_{\mathrm{p}}$, analysed according to their method, as the mobile fraction while they infer that the $\mathrm{Fe}_{0}$ comprises the mobile plus stable amorphous fractions, the latter representing the aged amorphous hydrous oxides accumulated in situ.

The difference between aged gels and the crystalline forms is, according to Van de Giessen (1966), merely a matter of crystallinity grade or crystal size, the aged gels or 'amorphous' iron oxides having a micro-crystallinity as could be shown by electron microscopy.

In more recent investigations McKeague et al. (1971) presented evidence that the oxalate-extractable iron is not so specifically inorganic as previously thought; it contains also part of the organic complexed iron, namely the Fe-fulvic acid complexes.

The latter are regarded as the most mobile of the organic complexed forms since they are easily soluble in water. The relationship between iron forms in soils and the existing differential solubility tests is shown in Table 1.

Although existing selective iron extractions have so far been mainly conducted with temperate soils the proposed chemical methods appear sufficiently realistic to investigate their usefulness for genetic studies of tropical soils, particularly those of a podzolic nature in which mobilization and transport of iron are important processes. A comperative study was therefore carried out on a selection of Sarawak upland soils of which the results are presented in this paper. 
Table 1. Iron forms in soils as extracted by specific methods.

$$
\mathrm{Fe}_{\mathrm{t}} \mathrm{Fe}_{\mathrm{d}} \quad \mathrm{Fe}_{\mathrm{o}} \quad \mathrm{Fe}_{\mathrm{p}}
$$
a. Silicate-bound iron and compound metal oxides such as ilmenite
b. Crystalline free iron oxides (mainly goethite and hematite)
c. Amorphous hydrous iron oxides (aged gels)
d. Fulvic acid complexed iron ('mobile fraction')
e. Iron in other organic forms
f. Magnetite

$\begin{array}{llll}\mathrm{X}^{1} & - & - & - \\ \mathrm{x} & \mathrm{x} & - & - \\ \mathrm{x} & \mathrm{x} & \mathrm{x} & - \\ \mathrm{x} & \mathrm{x} & \mathrm{x} & \mathrm{x} \\ \mathrm{x} & \mathrm{x} & - & \mathrm{x} \\ \mathrm{x} & \text { (small amounts) } & \text { (in part) } & -\end{array}$

$1 \mathrm{x}=$ extractable.

\section{Materials and methods}

Some particulars of the chosen soil series are given in Table 2. Full details are described by Andriesse $(1972,1975)$.

Samples of all horizons of the selected profiles were dried at $40{ }^{\circ} \mathrm{C}$ and thereafter the fine earth fracton $(<2 \mathrm{~mm})$ was obtained by gentle breaking of the structural elements and sieving. The fine earth was thereafter crushed to a particle size of less than $150 \mu \mathrm{m}$.

Dithionite extraction was carried out according to Mehra \& Jackson (1960), ammonium oxalate/oxalic acid extraction by the method proposed by McKeague \& Day (1966) and sodium pyrophosphate extraction according to McKeague (1967).

The iron in the extracts was measured by atomic absorption spectrophotometry (ASS) for which a Techtron, type AA4, was employed. Addition of lanthanum to the solutions is necessary to mask interferences. To avoid precipitation of lanthanum with ammonium oxalate and sodium pyrophosphate, the lanthanum solution should

Table 2. Main characteristics of selected upland soils from Sarawak.

\begin{tabular}{|c|c|c|c|c|c|}
\hline No & $\begin{array}{l}\text { Profile } \\
\text { name }\end{array}$ & Derivation & $\begin{array}{l}\text { Local soil } \\
\text { group }\end{array}$ & $\begin{array}{l}\text { USDA Soil } \\
\text { Taxonomy (1976) }\end{array}$ & $\begin{array}{l}\text { FAO/UNESCO } \\
\text { World Soil Legend } \\
\text { (1974) }\end{array}$ \\
\hline 1 & Tarat & Basalt & Lateritic & Typic Haplorthox & Orthic Ferralsol \\
\hline 2 & Gumbang & $\begin{array}{l}\text { Quartz } \\
\text { andesite }\end{array}$ & $\begin{array}{l}\text { Red-Yellow } \\
\text { Podzolic }\end{array}$ & Oxic Dystropept & Xanthic Ferralsol \\
\hline 3 & Serin & Arkose & $\begin{array}{l}\text { Red-Yellow } \\
\text { Podzolic }\end{array}$ & $\begin{array}{l}\text { Tropeptic } \\
\text { Haplorthox }\end{array}$ & Xanthic Ferralsol \\
\hline 4 & Semongok & $\begin{array}{l}\text { Shale/ } \\
\text { mudstone }\end{array}$ & $\begin{array}{l}\text { Red-Yellow } \\
\text { Podzolic }\end{array}$ & Typic Dystropept & Dystric Cambisol \\
\hline 5 & Gading * & Adamellite & $\begin{array}{l}\text { Red-Yellow } \\
\text { Podzolic }\end{array}$ & $\begin{array}{l}\text { 'Psammentic' } \\
\text { Haplorthox }\end{array}$ & Xanthic Ferralsol \\
\hline 6 & Nyalau * & $\begin{array}{l}\text { Quartz } \\
\text { sandstone }\end{array}$ & $\begin{array}{l}\text { Red-Yellow } \\
\text { Podzolic }\end{array}$ & $\begin{array}{l}\text { 'Psammentic' } \\
\text { Haplorthox }\end{array}$ & Xanthic Ferralsol \\
\hline
\end{tabular}

* These series represent border-cases between Ultisols and Oxisols. 
be prepared in $1.2 \mathrm{~N} \mathrm{HCl}$.

Measurements in the ammonium oxalate extracts were done two hours after addition of the lanthanum solution, whereas those in the pyrophosphate extracts had to be carried out before organic matter started to flocculate as a result of addition of lanthanum.

Interferences of foreign ions and components in the soil extract upon addition of lanthanum were not observed. Also, organic matter present in the pyrophosphate extract did not affect the measurements of iron.

Total iron was measured by X-ray fluorescence with a Philips PW 1540/15 unit with a $1.6 \mathrm{~kW}$ generator and $2 \mathrm{~kW}$ Cr tube.

\section{Results}

The results for the various extractable forms of iron are given in Table 3, but before discussing their implications some comments must be given on the obtained values.

Differences between $\mathrm{Fe}_{\mathrm{t}}$ and $\mathrm{Fe}_{\mathrm{d}}$ are a fair measure for presence of silicate bound iron and Blume and Schwertmann (1969) use this as a parameter to weathering stage. The values obtained are generally in agreement with the mineralogical composition of the soils as was investigated by the author (1975), but $\mathrm{Fe}_{\mathrm{d}}$ appears to be rather low since the mineralogy indicates the virtual absence of silicate-bound iron, and therefore $\mathrm{Fe}_{\mathrm{t}}$ and $\mathrm{Fe}_{\mathrm{d}}$ values should be almost the same. Tests in this laboratory indicate that the method advocated by Mehra \& Jackson (1960) suffers from the fact that the crucial extraction temperature of $80^{\circ} \mathrm{C}$ is difficult to maintain and that small deviations beneath this temperature result in extraction of considerably less iron. Probably, the method proposed by Holmgren (1967) which is based on a cold dithionite extraction but with prolonged shaking should give better results. The latter method, with some modifications, was tested out in this laboratory and gave consistently higher values for $\mathrm{Fe}_{\mathrm{d}}$, which could be reproduced with more accuracy than those obtained by the hot extraction method (Quak \& Mulder, 1975). The unexpected large differences between $\mathrm{Fe}_{\mathrm{i}}$ and $\mathrm{Fe}_{\mathrm{d}}$, particularly in soils with high amounts of $\mathrm{Fe}_{\mathrm{d}}$ are therefore explained by the limitations of the method used. (The negative value for $\mathrm{Fe}_{\mathrm{t}}-\mathrm{Fe}_{\mathrm{d}}$ in the $\mathrm{A}_{12}$ horizon of the Gading series is probably due to an analytical error.)

The $\mathrm{Fe}_{\mathrm{d}}$, but particularly the $\mathrm{Fe}_{0}$ values of the Gumbang series are probably influenced by the high magnetite content in samples of this profile, as shown by mineralogical studies. As indicated, both extracts remove iron from magnetite (Baril \& Bitton, 1966; Gamble \& Daniels, 1972).

The surface horizon of the Nyalau series is probably contaminated with eroded material from upslope areas because the $\mathrm{Fe}_{\mathrm{t}}$ content of that sample is anomalously high.

The $\mathrm{Fe}_{\mathrm{p}}$ values of surface horizons appear in general to be higher than $\mathrm{Fe}_{0}$ values, exceptions being the Gumbang and the Tarat series. For the Gumbang this exception may be explained by the fact that magnetite tends to give too high obtained $\mathrm{Fe}_{\mathrm{o}}$ values and in reality $\mathrm{Fe}_{\mathrm{p}}$ may be higher than $\mathrm{Fe}_{\mathrm{o}}$. In the Tarat series the difference may be of genetic significance. 
Table 3. Extractable and total iron in major Sarawak Upland soils.

\begin{tabular}{|c|c|c|c|c|c|c|}
\hline \multirow[t]{2}{*}{ Soil series } & \multirow{2}{*}{$\begin{array}{l}\text { Depth } \\
\text { (cm) }\end{array}$} & \multirow[t]{2}{*}{ Horizon } & \multirow{2}{*}{$\begin{array}{l}\text { Total } \\
\mathrm{Fe}_{2} \mathrm{O}_{3}(\%)\end{array}$} & \multicolumn{3}{|c|}{ Extractable $(\%)$ by } \\
\hline & & & & $\begin{array}{l}\text { sodium } \\
\text { dithionite }\end{array}$ & $\begin{array}{l}\text { ammonium } \\
\text { oxalate }\end{array}$ & $\begin{array}{l}\text { sodium } \\
\text { pyrophosphate }\end{array}$ \\
\hline Tarat & $\begin{array}{c}0-8 \\
8-28 \\
28-54 \\
54-100\end{array}$ & $\begin{array}{l}A_{1} \\
B_{1} \\
B / C \\
C\end{array}$ & $\begin{array}{l}25.4 \\
26.1 \\
27.0 \\
25.2\end{array}$ & $\begin{array}{l}14.64 \\
16.65 \\
15.44 \\
16.02\end{array}$ & $\begin{array}{l}1.06 \\
0.66 \\
0.54 \\
0.34\end{array}$ & $\begin{array}{l}0.82 \\
0.54 \\
0.09 \\
0.02\end{array}$ \\
\hline Gumbang & $\begin{array}{c}0-9 \\
9-28 \\
28-44 \\
44-67 \\
67-100\end{array}$ & $\begin{array}{l}\mathrm{A}_{1} \\
\mathrm{~B}_{1} \\
\mathrm{~B}_{2} \\
\mathrm{~B} / \mathrm{C} \\
\mathrm{C}\end{array}$ & $\begin{array}{l}2.7 \\
3.8 \\
3.4 \\
3.5 \\
3.9\end{array}$ & $\begin{array}{l}1.37 \\
1.60 \\
2.00 \\
2.06 \\
2.35\end{array}$ & $\begin{array}{l}0.61 \\
0.54 \\
0.37 \\
0.22 \\
0.20\end{array}$ & $\begin{array}{l}0.47 \\
0.44 \\
0.33 \\
0.21 \\
0.19\end{array}$ \\
\hline Serin & $\begin{array}{c}0-10 \\
10-25 \\
25-75 \\
75-115 \\
115-135\end{array}$ & $\begin{array}{l}A_{1} \\
A_{2}(E) \\
B_{1} \\
B_{2} \\
B / C\end{array}$ & $\begin{array}{l}4.4 \\
5.5 \\
5.5 \\
6.9 \\
6.4\end{array}$ & $\begin{array}{l}3.60 \\
4.18 \\
4.00 \\
4.86 \\
4.86\end{array}$ & $\begin{array}{l}0.37 \\
0.39 \\
0.20 \\
0.11 \\
0.09\end{array}$ & $\begin{array}{l}0.59 \\
0.53 \\
0.13 \\
0.04 \\
0.00\end{array}$ \\
\hline Semongok & $\begin{array}{c}0-9 \\
9-29 \\
29-68 \\
75-88 \\
88-115\end{array}$ & $\begin{array}{c}\mathrm{A}_{1} \\
\mathrm{~B}_{1} \\
\mathrm{~B}_{2} \\
\mathrm{IIB}_{2} \\
\mathrm{IIB} / \mathrm{C}\end{array}$ & $\begin{array}{l}5.5 \\
5.3 \\
4.4 \\
8.7 \\
8.0\end{array}$ & $\begin{array}{l}2.92 \\
3.37 \\
3.66 \\
4.46 \\
3.55\end{array}$ & $\begin{array}{l}0.83 \\
0.61 \\
0.60 \\
0.50 \\
0.50\end{array}$ & $\begin{array}{l}0.89 \\
0.83 \\
0.96 \\
0.56 \\
0.37\end{array}$ \\
\hline Gading & $\begin{array}{c}0-7 \\
17-20 \\
30-50 \\
70-100 \\
100-120 \\
>120\end{array}$ & $\begin{array}{l}A_{1} \\
A_{12} \\
B_{1} \\
B_{21} \\
B_{22} \\
C *\end{array}$ & $\begin{array}{l}2.7 \\
2.4 \\
2.9 \\
5.2 \\
5.3 \\
6.6\end{array}$ & $\begin{array}{l}2.17 \\
2.52 \\
2.80 \\
4.35 \\
4.98 \\
2.57\end{array}$ & $\begin{array}{l}0.26 \\
0.23 \\
0.21 \\
0.11 \\
0.10 \\
0.23\end{array}$ & $\begin{array}{l}0.51 \\
0.57 \\
0.46 \\
0.06 \\
0.03 \\
0.04\end{array}$ \\
\hline Nyalau & $\begin{array}{c}0-9 \\
9-30 \\
30-63 \\
63-110 \\
110-150\end{array}$ & $\begin{array}{l}A_{1} \\
A_{2}(E) \\
B_{1} \\
B_{2} \\
B / C\end{array}$ & $\begin{array}{l}5.7 \\
2.8 \\
2.1 \\
4.3 \\
3.8\end{array}$ & $\begin{array}{l}1.09 \\
1.94 \\
1.83 \\
2.63 \\
2.86\end{array}$ & $\begin{array}{l}0.26 \\
0.31 \\
0.20 \\
0.09 \\
0.07\end{array}$ & $\begin{array}{l}0.33 \\
0.40 \\
0.23 \\
0.09 \\
0.09\end{array}$ \\
\hline
\end{tabular}

* Weathered rock discontinuity.

Noteworthy is, however, that in soils so far studied by Bascomb (1968). McKeague \& et al. (1971) and Ball \& Beaumont (1972) the pyrophosphate-extractable iron was always lower than the oxalate-extractable iron. All these authors worked with soils from temperate regions, in which much of the organic iron fraction consists of fulvic acid complexes. The fact that $\mathrm{Fe}_{\mathrm{p}}$ exceeds $\mathrm{Fe}_{0}$ in most of the humid tropical soils reported here, shows that the interpretation of the difference $\left(\mathrm{Fe}_{0}\right.$ minus $\left.\mathrm{Fe}_{\mathrm{p}}\right)$ as aged 'amorphous' oxides breaks down, and that there must be a fraction of the iron extracted by pyrophosphate and not by oxalate. This fraction may well be organic, but of a different nature from the main organic-bound iron fractions in the soils of temperate regions studied by the quoted authors. (See note on page 12.) 

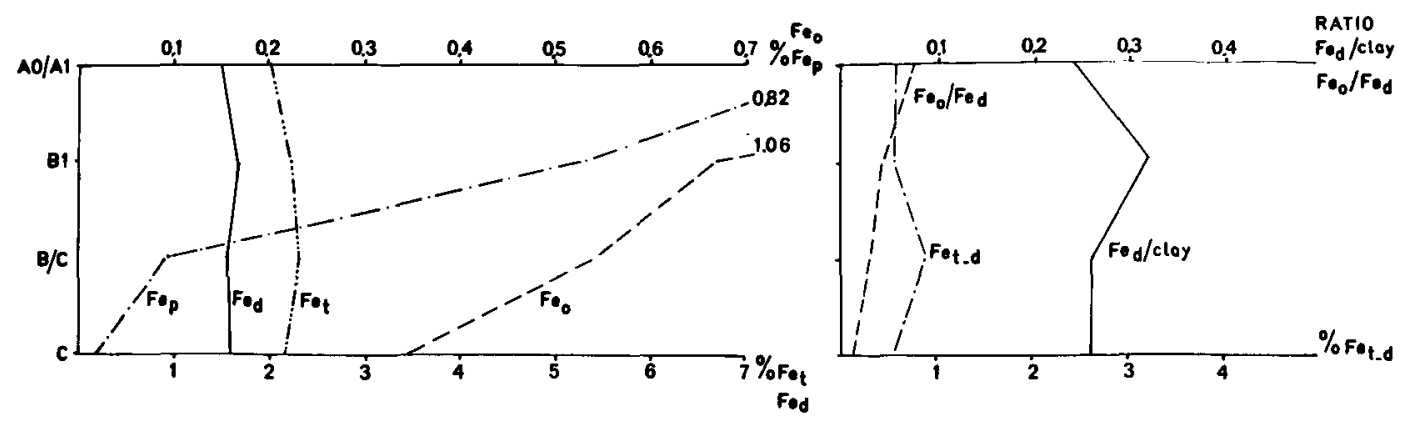

II

OXIC DYSTROPEPT, GUMBANG PROFILE
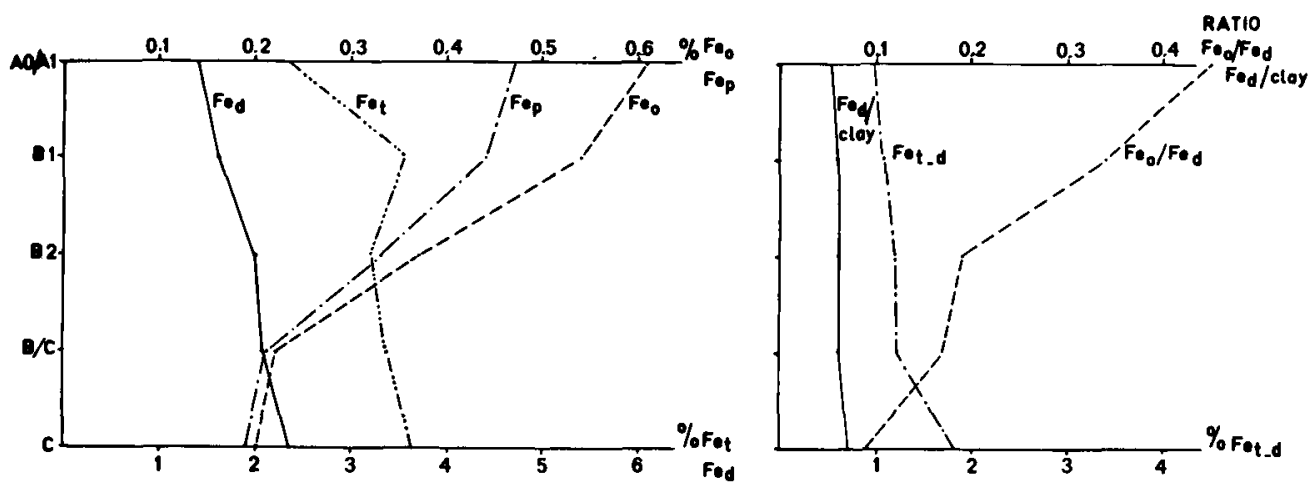

III

TROPEPTIC HAPLORTHOX, SERIN PROFILE
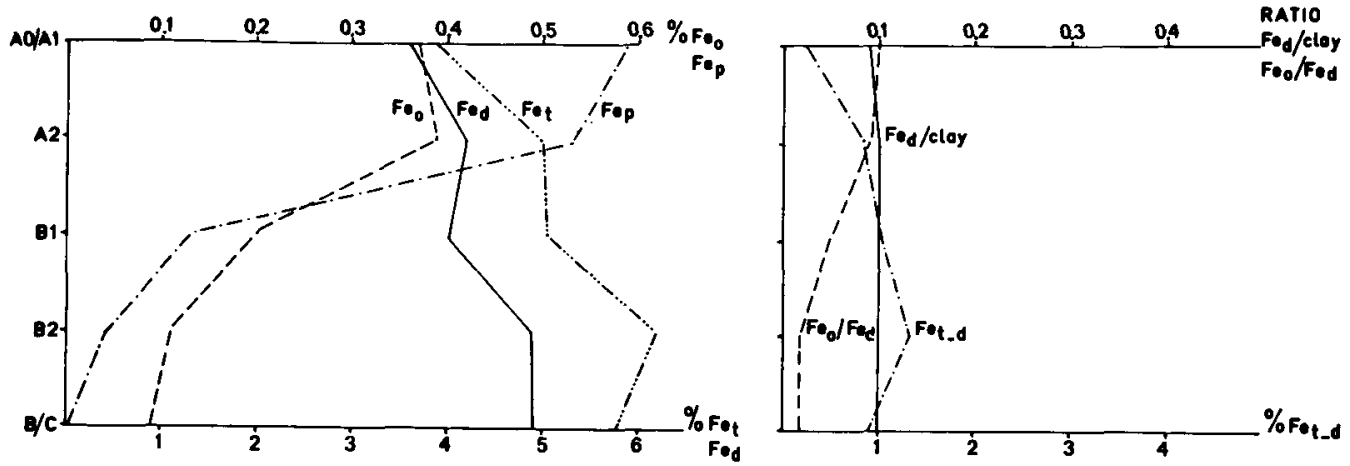

Fig. 1. Depth functions of various iron extraction forms $\left(\mathrm{Fe}_{0}=\right.$ ammonium oxalate; $F \mathrm{e}_{\mathrm{p}}=$ sodium pyrophosphate; $\mathrm{Fe}_{\mathrm{d}}=$ sodium dithionite/citrate; $\mathrm{Fe}_{\mathrm{t}}=$ total) and derived relationships of main upland soils in West Sarawak. 

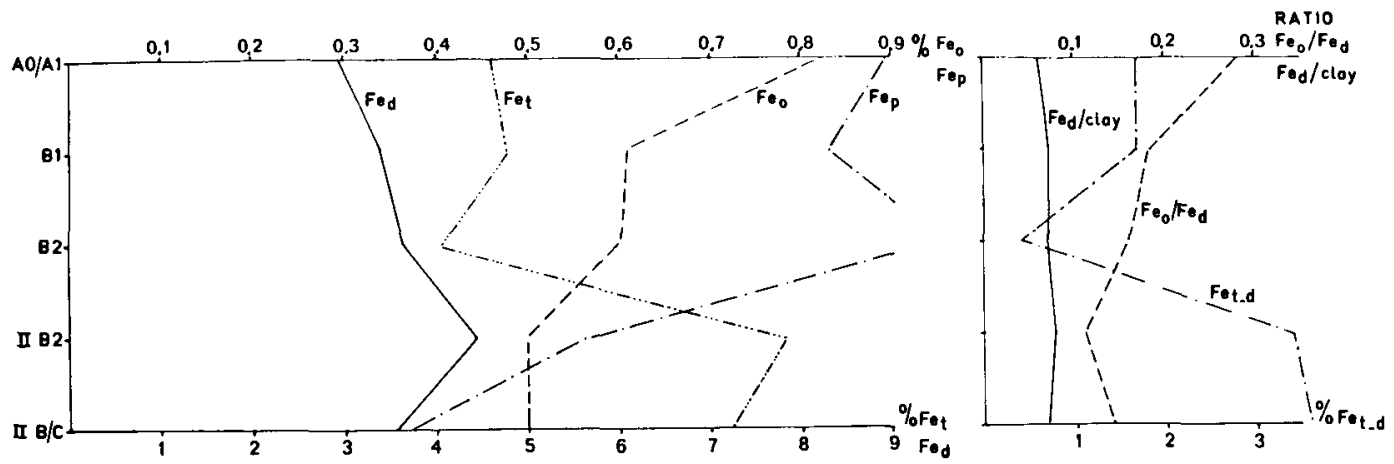

II

psammentic haplontox (gRanite derived), gading profile
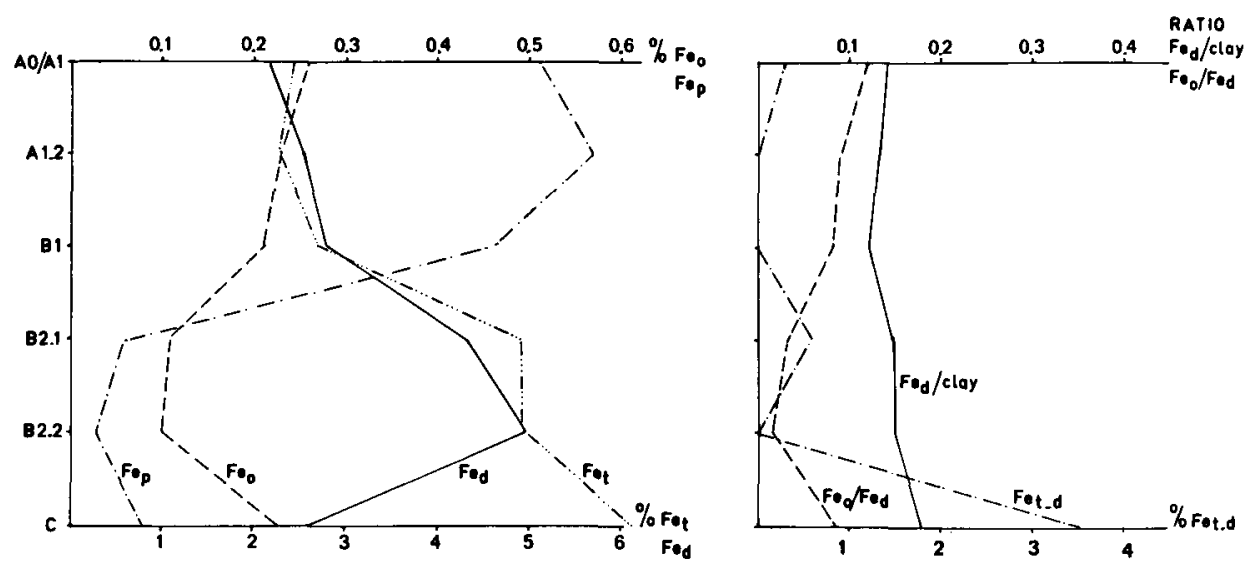

II PSAMmentic haplortox, (sandstone derived), nyalau profile
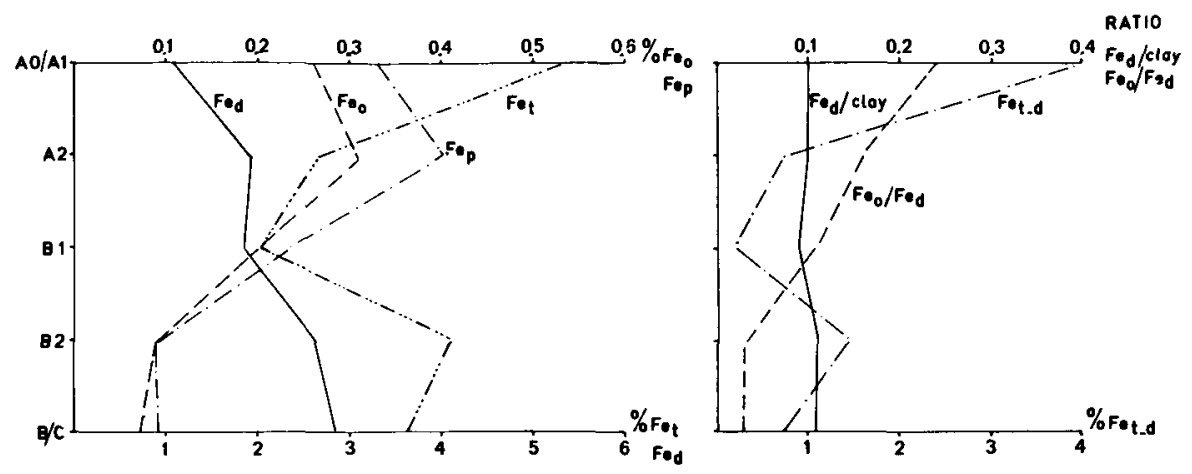

Fig. 1. (continued).

Neth. J. agric. Sci. 27 (1979) 


\section{Genetic implications}

Depth functions of the various iron forms and derived ratios were prepared from the values given in Table 3. The depth functions are shown in Fig. 1.

The following observations can be made. $\mathrm{Fe}_{\mathrm{i}}-\mathrm{Fe}_{\mathrm{d}}$ is a parameter for judging weathering stage of the soil unless high amounts of magnetite and ilmenite are present. In the selected soils $\mathrm{Fe}_{\mathrm{d}}$ amounts to $75 \%$ or more of the total iron, which indicates that all soils are highly weathered.

The $\mathrm{Fe}_{\mathrm{d}}$ values increase and the amounts of $\mathrm{Fe}_{\mathrm{o}}$ and $\mathrm{Fe}_{\mathrm{p}}$ decrease with depth in all profiles, which suggests that the degree of crystallinity of iron oxides increases with depth. This is also apparant from the decreasing 'iron activity' ratios $\left(\mathrm{Fe}_{\mathrm{o}} / \mathrm{Fe}_{\mathrm{d}}\right)$ which, according to Blume \& Schwertmann (1969), would indicate a high degree of aging in subsoils and high iron activity in topsoils. If the observed increase in pedogenetic or free iron in the subsoils would be the result of recent or continuing removal of free iron from the topsoils with subsequent accumulation in the subsoil, one would expect the amount of 'aged gels' to increase with depth since these represent transitional stages from the mobile fraction removed from the surface horizons to the crystalline fraction accumulating in the subsoil.

Such 'aged gels' are extracted by oxalate but since this agent also extracts fulvic acid complexed iron regarded as the mobile fraction, the amount of 'aged gels' is difficult to judge from $\mathrm{Fe}_{0}$ values alone.

This can, however, be approximated from the relationship existing between $\mathrm{Fe}_{\mathrm{o}}$ and $\mathrm{Fe}_{\mathrm{p}}$. Since $\mathrm{Fe}_{\mathrm{o}}$ represents 'aged gels' plus fulvic acid complexed iron, and $\mathrm{Fe}_{\mathrm{p}}$ all organic complexed iron, a relation between $\mathrm{Fe}_{0}$ and $\mathrm{Fe}_{\mathrm{p}}$ can only point to a high relative importance of fulvic complexed iron in both extractions.

Fig. 1 shows such a close relationship suggesting that the proportion of 'aged gels' in $\mathrm{Fe}_{0}$ is indeed low. Although the diminishing content of $\mathrm{Fe}_{0}$ with depth may be largely a function of decreasing content of fulvic acid complexed iron it could obscure a possible increase of very low absolute amount of the 'aged gels' occurring at depth. This would then be so insignificant, however, that it cannot explain the comparatively large difference between the crystalline iron compounds (approximated by $\mathrm{Fe}_{\mathrm{d}}-\mathrm{Fe}_{\mathrm{o}}$ ) and the amorphous compounds indicated as $\mathrm{Fe}_{0}$. This absence or near absence of a transitory iron form (aged gels) in the subsoils is of genetic importance since it implies a very low rate of accumulation or absence of a new accumulation process. Only in the Tarat series there may be significant new accumulation, because in this profile the amounts of 'aged gels' are proportionally more important, as suggested by the substantial difference between $\mathrm{Fe}_{\mathrm{o}}$ and $\mathrm{Fe}_{\mathrm{p}}$ figures.

The significant amounts of organic complexed iron forms particularly in the surface horizons suggest a high activity of the organic matter in mobilizing iron. Since it is mainly the fulvic acid part of the mineralized organic material which plays an active role in the mobilization of iron (Oades, 1963; Segalen, 1964), the relative contents of fulvic acids in the soils would be an important pointer to the magnitude of iron removal.

Table 4, derived from Andriesse (1975), shows that indeed in all samples fulvic acids are dominant over humic acids, surface soils of some profiles forming the only 
Table 4. $\mathrm{C} / \mathrm{N}$ ratios, humic and fulvic acid contents of mineral horizons of main Upland soils in West Sarawak.

\begin{tabular}{|c|c|c|c|c|c|c|c|c|}
\hline \multirow[t]{2}{*}{ Soil series } & \multirow[t]{2}{*}{ Horizon } & \multirow{2}{*}{$\begin{array}{l}\text { C in dry } \\
\text { fine earth } \\
(\%)\end{array}$} & \multirow{2}{*}{$\begin{array}{l}\mathrm{N} \text { in dry } \\
\text { fine earth } \\
(\%)\end{array}$} & \multirow[t]{2}{*}{$\mathrm{C} / \mathrm{N}$ ratio } & \multicolumn{3}{|c|}{$\begin{array}{l}\text { Contribution (mg) per } \\
\mathrm{g} \mathrm{C} \text { in dry fine earth }\end{array}$} & \multirow{2}{*}{$\begin{array}{l}\text { Humic acid/ } \\
\text { fulvic acid } \\
\text { ratio }\end{array}$} \\
\hline & & & & & $\begin{array}{l}\text { humic } \\
\text { acid }\end{array}$ & $\begin{array}{l}\text { fulvic } \\
\text { acid }\end{array}$ & total & \\
\hline Tarat & $\begin{array}{l}A_{1} \\
B_{1} \\
B / C \\
C\end{array}$ & $\begin{array}{l}4.61 \\
1.40 \\
0.93 \\
0.44\end{array}$ & $\begin{array}{l}0.48 \\
0.18 \\
0.10 \\
0.05\end{array}$ & $\begin{array}{l}9.6 \\
7.8 \\
9.3 \\
8.8\end{array}$ & $\begin{array}{l}6.9 \\
2.0 \\
2.7 \\
2.0\end{array}$ & $\begin{array}{r}8.2 \\
11.2 \\
7.8 \\
5.2\end{array}$ & $\begin{array}{r}15.1 \\
13.2 \\
10.5 \\
7.2\end{array}$ & $\begin{array}{l}0.84 \\
0.18 \\
0.35 \\
0.39\end{array}$ \\
\hline Gumbang & $\begin{array}{l}\mathbf{A}_{1} \\
\mathbf{B}_{\mathbf{1}} \\
\mathbf{B}_{\mathbf{2}} \\
\mathrm{B} / \mathrm{C} \\
\mathrm{C}\end{array}$ & $\begin{array}{l}5.51 \\
1.02 \\
0.62 \\
0.43 \\
0.39\end{array}$ & $\begin{array}{l}0.45 \\
0.11 \\
0.06 \\
0.05 \\
0.04\end{array}$ & $\begin{array}{r}12.2 \\
9.3 \\
10.3 \\
8.6 \\
9.8\end{array}$ & $\begin{array}{r}10.4 \\
2.0 \\
2.0 \\
1.2 \\
1.7\end{array}$ & $\begin{array}{l}8.0 \\
5.3 \\
3.6 \\
3.3 \\
2.5\end{array}$ & $\begin{array}{r}18.4 \\
7.3 \\
5.6 \\
4.5 \\
4.2\end{array}$ & $\begin{array}{l}1.30 \\
0.37 \\
0.56 \\
0.36 \\
0.68\end{array}$ \\
\hline Serin & $\begin{array}{l}A_{1} \\
A_{2}(E) \\
B_{1} \\
B_{2} \\
B / C\end{array}$ & $\begin{array}{l}2.52 \\
0.76 \\
0.51 \\
0.37 \\
0.15\end{array}$ & $\begin{array}{l}0.25 \\
0.09 \\
0.08 \\
0.03 \\
0.02\end{array}$ & $\begin{array}{r}10.1 \\
8.9 \\
10.2 \\
12.3 \\
7.5\end{array}$ & $\begin{array}{l}5.4 \\
1.4 \\
1.8 \\
1.6 \\
2.9\end{array}$ & $\begin{array}{l}9.7 \\
5.3 \\
2.6 \\
1.5 \\
-\end{array}$ & $\begin{array}{r}15.1 \\
6.8 \\
4.4 \\
3.1 \\
2.9\end{array}$ & $\begin{array}{l}0.56 \\
0.26 \\
0.47 \\
1.06 \\
-\end{array}$ \\
\hline Semongok & $\begin{array}{c}\mathrm{A}_{1} \\
\mathrm{~B}_{1} \\
\mathrm{~B}_{2} \\
\mathrm{IIB}_{2} \\
\mathrm{IIB} / \mathrm{C}\end{array}$ & $\begin{array}{l}3.18 \\
0.86 \\
0.57 \\
0.36 \\
0.26\end{array}$ & $\begin{array}{l}0.27 \\
0.11 \\
0.08 \\
0.06 \\
0.09\end{array}$ & $\begin{array}{r}11.7 \\
7.8 \\
7.1 \\
6.0 \\
2.9\end{array}$ & $\begin{array}{r}12.1 \\
2.4 \\
2.1 \\
2.7 \\
1.4\end{array}$ & $\begin{array}{l}7.2 \\
4.8 \\
3.3 \\
1.8 \\
2.8\end{array}$ & $\begin{array}{r}19.3 \\
7.2 \\
5.4 \\
4.5 \\
4.2\end{array}$ & $\begin{array}{l}1.70 \\
0.50 \\
0.64 \\
1.50 \\
0.50\end{array}$ \\
\hline Gading & $\begin{array}{l}A_{1} \\
A_{12} \\
B_{1} \\
B_{21} \\
B_{22}\end{array}$ & $\begin{array}{l}1.69 \\
0.63 \\
0.27 \\
0.22 \\
0.21\end{array}$ & $\begin{array}{l}0.13 \\
0.09 \\
0.03 \\
0.02 \\
0.03\end{array}$ & $\begin{array}{r}13.2 \\
7.2 \\
8.0 \\
10.0 \\
7.6\end{array}$ & $\begin{array}{l}3.8 \\
1.0 \\
0.5 \\
0.7 \\
0.3\end{array}$ & $\begin{array}{l}5.5 \\
4.6 \\
3.1 \\
4.0 \\
1.8\end{array}$ & $\begin{array}{l}9.3 \\
5.6 \\
3.6 \\
4.7 \\
2.1\end{array}$ & $\begin{array}{l}0.69 \\
0.22 \\
0.14 \\
0.18 \\
0.17\end{array}$ \\
\hline Nyalau & $\begin{array}{l}A_{1} \\
A_{2}(E) \\
B_{1} \\
B_{2} \\
B / C\end{array}$ & $\begin{array}{l}4.23 \\
0.54 \\
0.19 \\
0.19 \\
0.09\end{array}$ & $\begin{array}{l}0.25 \\
0.08 \\
0.03 \\
0.02 \\
0.03\end{array}$ & $\begin{array}{r}16.9 \\
6.8 \\
6.3 \\
9.5 \\
3.0\end{array}$ & $\begin{array}{l}9.5 \\
1.2 \\
0.7 \\
0.5 \\
0.7\end{array}$ & $\begin{array}{l}7.1 \\
2.9 \\
1.5 \\
1.6 \\
1.6\end{array}$ & $\begin{array}{r}16.6 \\
4.1 \\
2.2 \\
2.1 \\
2.3\end{array}$ & $\begin{array}{l}1.34 \\
0.41 \\
0.47 \\
0.31 \\
0.43\end{array}$ \\
\hline
\end{tabular}

exceptions. The mobilization of iron in the surface horizons through complexing with fulvic acids would be most effective for iron present in the colloidal fraction and the relation between pedogenetic iron and clay was therefore expressed in a diagrammatic form in Figs 1 and 2 by the $\mathrm{Fe}_{\mathrm{d}}$ /clay ratios. A strong relationship between clay content and free iron can be seen in the Serin, Semongok and Nyalau profiles. It may be coincidental that these profiles also represent the only soils developed on sedimentary rocks but it could suggest a possible relationship with the mode in which iron is found in the parent materials derived from them. In the present cases, this is mainly as finely divided goethite. This would tend to accumulate in the colloidal fraction upon weathering. 


\section{Discussion}

These analytical results lead to the conclusion that there has been iron removal in varying degree from the surface horizons in all soils. However, there is no evidence for any appreciable recent accumulation in the lower horizons. The $F_{d}$ values within the soil profiles do indicate that some sort of accumulation process must have taken place but the highly crystalline nature of this fraction points to great age. Although the presence of 'aged gels' in lower horizons of some profiles cannot be discounted, they seem to play a very secondary role in any accumulation process.

In addition to this evidence of a probable 'fossil' accumulation process of iron within the normal profile depth, there is substantial field information that hard limonite sheets have formed in cracks and joints of argillaceous rocks such as those underlying the Semongok series. In Sarawak this is generally the case in carbonaceous shales and sandstones of littoral origin (Andriesse, 1972). An explanation for both types of iron accumulation, that occurring at great depth and that present within the profile depth is therefore required.

Andriesse (1970), when studying the development of the Podzol morphology in an age sequence of coastal sands in Sarawak, found that an intermediate 'red weathering' stage occurs, largely as a result of weathering of ilmenite to leucoxene and free iron oxides, before removal of iron oxides from surface horizons and deelopment of the full Podzol morphology. The results of the present study suggest that in the upland soils, likewise, two stages of iron accumulation and mobilization can be recognized: an early stage of relative iron accumulation (rubefaction) caused by weathering of the primary minerals and desilication, followed by a stage of iron mobilization and removal from the surface horizons.

The nature of this latter process is not yet clear. Several possibilities come to mind.

- Argilluviation and subsequent weathering of iron-rich clay. The present percentage aluminium saturation is too high for argilluviation. Some non-continuous, partly weathered ferriargillans observed in thin sections indicate that the process may have been active in the past (Andriesse, 1972, 1975).

- Cheluviation by fulvic acids. Iron transport by fulvic acids may be assumed to stop as soon as the metal/fulvic ration becomes high enough (cf. experiments by Schnitzer \& Skinner, 1964, who demonstrated the insoluble nature of such complexes). The appreciable amounts of free iron oxides in the upper horizons, much in excess of the contents in Podzols, would contribute iron to, and hence precipitate, possible ferricfulvic complexes after only a short distance of transport. Moreover, no horizon of organic matter accumulation has been observed in the profiles, so that this possibility must be ruled out.

- Reduction and transport in ferrous form. Most of the soils are well drained but could possibly have been imperfectly or poorly drained before the dissection of the landscape to the present local base level. Reduction and transport of ferrous iron in these soils would be at most fossil, if it has taken place at all.

Transport of ferric and ferrous iron mobilized by the oxidation of pyrite in extremely acid conditions may explain the formation of the limonite sheets at great 
depth (but not the iron oxide accumulations in all the soil profiles). Soils in some localities (e.g. Semongok series) are imperfectly drained and in addition, the sedimentary parent rocks of most of these contain pyrite. Strong acidification due to oxidation in the initial stage of soil development could have mobilized iron in ferric form. Under these conditions large amounts of ferrous iron may also have been transported downward. This process may even continue until the present, but at considerable depth, in the present weathering front of the rocks.

\section{Conclusions}

The iron oxides accumulated in subsoils within the profile depth are most probably related to a fossil argilluviation process, followed by weathering of iron-rich clay. Other possible mechanisms for this accumulation appear unlikely, although, transport under supposed poorly drained conditions prior to the dissection of the present landscape remains theoretically possible. The present high chelating activity in the surface horizons as evidenced by the relatively high amounts of fulvic acids cannot be considered responsible for the iron translocation. The fact that $\mathrm{Fe}_{\mathrm{p}}$ exceeds $\mathrm{Fe}_{\mathrm{o}}$ in most soils, in contrast to the situation in soils of the temperate zone may point to a difference in the kinds of Fe-organic complexes occurring in these two environments. (See note on p. 12.)

The limonite sheets in joints and cracks of sedimentary rocks at great depth below the soil profile are most probably formed by an oxidation and precipitation of ferrous iron and precipitation of ferric iron mobilized through the initial oxidation of pyrites in the weathering front of these rocks. This is a continuing process but not related to the iron distribution patterns within the normal profile depth. An aspect worth investigating is the degree to which lateral rather than vertical movement of soil water has played a role in this iron accumulation process.

\section{Acknowledgments}

I am indebted to Dr R. Brinkman for his suggested amendments to the manuscript.

\section{References}

Andriesse, J. P., 1970. The development of the Podzol morphology in the Tropical Lowlands of Sarawak (Malaysia). Geoderma 3: 261-279.

Andriesse, J. P., 1972. Soils of West Sarawak. Memoir 1. Soils Division, Department of Agriculture. Government Printer, Sarawak.

Andriesse, J. P., 1975. Characteristics and formation of so-called Red-Yellow Podzolic Soils in the humid tropics (Sarawak, Malaysia). Ph.D. thesis, State University, Utrecht. Commun. Royal Trop. Inst., Amsterdam No 66.

Ball, D. F. \& P. Beaumont, 1972. Vertical distribution of extractable iron and aluminium in soil profiles from a Brown Earth-Peaty Podzol Association. J. Soil Sci. 23: 298-308.

Baril, R. \& G.: Bitton, 1967. Anomalous values of free iron in some Quebec soils containing magnetite. Can. J. Soil Sci. 47: 261.

Bascomb, C. L., 1968. Distribution of pyrophosphate extractable iron and organic carbon in soils of various groups. J. Soil Sci. 19: 251-268. 
Blume, H. P. \& V. Schwertmann, 1969. Genetic evaluation of profile distribution of aluminium, iron and manganese oxides. Proc. Soil Sci. Soc. Am. 33: 438-444.

FAO/UNESCO, 1974. Soil map of the world, Vol. 1, legend. (Advanced copy). UNESCO, Paris.

Gamble, E. E. \& R. B. Daniels, 1972. Iron and silica in water, acid ammonium oxalate and dithionite extracts of some North Carolina Coastal Plain Soils. Proc. Soil Sci. Soc. Am. 36: 939-943.

Giessen, A. M. van de, 1966. Hydratatie en hydrolyse, II. De hydrolyse van oplossingen van Fe (III) nitraat. Chem. Weekbl. 62: 305.

Holmgren, O. O. S., 1967. A rapid citrate-dithionite extractable iron procedure. Proc. Soil Sci. Soc. Am. 31: 210.

McKeague, J. A., 1966. An evaluation of $0.1 \mathrm{M}$ pyrophosphate and pyrophosphate-dithionite in comparison with oxalate as extractants of the accumulation products in Podzols and some other soils. Can. J. Soil Sci. 47: 95-99.

McKeague, J. A. \& J. H. Day, 1966. Dithionite' and oxalate-extractable $\mathrm{Fe}$ and $\mathrm{Al}$ as aids in differentiating various classes of soils. Can. J. Soil Sci. 46: 13-22.

McKeague, J. A., J. E. Brydon \& N. M. Miles, 1971. Differentiation of forms of Extractable iron and aluminium in soils. Proc. Soil Sci. Soc. Am. 35: 33-38.

Mehra, O. P. \& M. L. Jackson, 1960. Iron oxide removal from soils and clays by a dithionitecitrate system buffered with sodium bi-carbonate. Clays Clay Minerals 7: 317-327.

Oades, J. M., 1963. The nature and distribution of iron compounds in soils. Soils Fertil. 26: 89-97.

Quak, J. A. \& C. Mulder, 1975. Versnelling van de bepaling van vrij ijzer d.m.v. een koude dithioniet extractie. Internal report AO68-BO30, Royal Tropical Institute, Amsterdam.

Schnitzer, M. \& S. I. M. Skinner, 1964. Organo-metallic interactions in soils. 3. Properties of iron- and aluminium organic matter complexes prepared in the laboratory and extracted from a soil. Soil Sci. 98: 197-203.

Schwertmann, V., 1959. Die fraktionierte Extraktion der freien Eisenoxide in Boden, ihre mineralogischen Formen und ihre Entstehungsweisen. Z. Pfl.Ernähr. Düng. Bodenk. 84: 194-204.

Schwertmann, V., 1964. Differenzierung der Eisenoxidide des Bodens durch Extraction mit $\mathrm{NH}_{4}$-Ozalat-Lösung. Z. Pfl.Ernähr. Düng. Bodenk. 105: 194-202.

Segalen, P., 1964. Le fer dans les sols. Publ. No 4, ORSTOM, Paris.

USDA, Soil Survey staff, 1976. Soil taxonomy.

\section{Note}

Subsequent to the finalization of this manuscript I was made aware of the work done by Wada \& Higashi (1976) with humus complexes of Andosols. Their studies indicate that pyrophosphate does little dissolve young humus forms but extracts large amounts from the older forms, presumably because of the higher amounts of mobile aluminium. It is suggested that humus forms of temperate and tropical regions may differ likewise. Also, recent work of Taylor \& Schwertmann (1978) indicates that soils with a high Al-level iron in the Fe(II) system had a preference to form goethite upon oxidation with a high possibility for Al to partly substitute $\mathrm{Fe}$ in the goethite. Herbillon (pers. comm.) suggests that this aluminiferous goethite might also be preferentially dissolved by pyrophosphate causing the $\mathrm{Fe}_{\mathrm{p}}$ to become higher than $\mathrm{Fe}_{0}$.

Wada, K. \& T. Higashi, 1976. The categories of Al- and Fe-humus complexes in Andosols determined by selective dissolution. J. Soil Sci. 27: 357-368.

Taylor, R. M. \& K. Schwertmann, 1978. The influence of aluminium on iron oxides. Part I. The influence of $\mathrm{Al}$ on $\mathrm{Fe}$ oxide formation from the $\mathrm{Fe}(\mathrm{II})$ system. Clays Clay Minerals 26: 373-383. 